\title{
Shorter telomere lengths in patients with severe COVID-19 disease
}

\author{
Raul Sanchez-Vazquez ${ }^{1,{ }^{*}}$, Ana Guío-Carrión ${ }^{1,{ }^{*}}$, Antonio Zapatero-Gaviria ${ }^{2}$, Paula Martínez ${ }^{1}$, \\ Maria A. Blasco ${ }^{1}$ \\ ${ }^{1}$ Telomeres and Telomerase Group, Molecular Oncology Program, Spanish National Cancer Centre (CNIO), \\ Melchor Fernández Almagro 3, Madrid, Spain \\ ${ }^{2}$ Field Hospital COVID-19, IFEMA, Madrid, Spain \\ *Equal contribution
}

Correspondence to: Maria A. Blasco; email: mblasco@cnio.es

Keywords: SARS-CoV-2, COVID-19, telomeres, aging

Received: December 11, 2020 Accepted: December 22, 2020

Published: January 11, 2021

Copyright: (C) 2020 Sanchez-Vazquez et al. This is an open access article distributed under the terms of the Creative Commons Attribution License (CC BY 3.0), which permits unrestricted use, distribution, and reproduction in any medium, provided the original author and source are credited.

\section{ABSTRACT}

The incidence of severe manifestations of COVID-19 increases with age with older patients showing the highest mortality, suggesting that molecular pathways underlying aging contribute to the severity of COVID-19. One mechanism of aging is the progressive shortening of telomeres, which are protective structures at chromosome ends. Critically short telomeres impair the regenerative capacity of tissues and trigger loss of tissue homeostasis and disease. The SARS-CoV-2 virus infects many different cell types, forcing cell turn-over and regeneration to maintain tissue homeostasis. We hypothesize that presence of short telomeres in older patients limits the tissue response to SARS-CoV-2 infection. We measure telomere length in peripheral blood lymphocytes COVID-19 patients with ages between 29 and 85 years-old. We find that shorter telomeres are associated to increased severity of the disease. Individuals within the lower percentiles of telomere length and higher percentiles of short telomeres have higher risk of developing severe COVID-19 pathologies.

\section{INTRODUCTION}

The current COVID-19 pandemic (https://www.who.int/) is produced by the SARS-CoV-2 virus, a novel zoonotic Coronavirus of the betacoronavirus genus that most likely crossed species from bats to humans leading to a pneumonia outbreak initially reported in Wuhan, China and now affecting the majority of countries. SARS-CoV2 causes from mild flu-like symptoms in approximately $80 \%$ of the cases to a severe lung and multi-organic failure which can result in death of a significant percentage of patients. Pathologies associated with SARS-CoV-2 include severe lung failure, diarrhea, heart infarct, and brain pathologies among others [1-3]. This wide viral tropism is mediated by expression of the Angiotensin-converting enzyme 2 (ACE2), which acts as the receptor protein for the virus to enter the host cells. In particular, the SARS-CoV-2 spike protein directly binds the ACE2 human protein [4-7]. The human ACE protein is expressed in alveolar type II (ATII) cells in the lung
[8], as well as in the kidney, the heart and the gut [9-14]. This expression pattern of the ACE protein explains that a preferential site for SARS-CoV-2 infection is the lung $[4,15,16]$, although the virus can also infect kidney, intestine, and heart cells causing severe pathologies in all these tissues [1-3, 11, 17, 18]. In this regard, it caught our attention that a common outcome of SARS-CoV-2 infection seems to be induction of fibrosis-like phenotypes in the lung and kidney, suggesting that the viral infection maybe exhausting the regenerative potential of tissues [11, 16-18].

In contrast to influenza infection, that causes a high mortality in infants [19-24], SARS-CoV-2 infection causes low mortality in infants or children but results in a progressively increased mortality with increasing age reaching up to $15 \%$ mortality in individuals that are $\geq 80$ years old (see https://covid19.isciii.es/ for mortality data in Spain). These findings suggest that molecular mechanisms at the origin of organismal aging maybe 
influencing the outcome of SARS-CoV-2 infection by increasing lethality. One of such molecular events underlying aging is the progressive shortening of telomeres throughout life, which can cause exhaustion of the proliferative potential of stem cells and immune cells among others [25-27].

Telomeres are specialized structures at the chromosome ends, which are essential for chromosome-end protection and genomic stability [28]. Vertebrate telomeres consist of tandem repeats of the TTAGGG DNA sequence bound by a six-protein complex known as shelterin, which prevents chromosome end-to-end fusions and telomere fragility $[29,30]$. As cells divide and DNA has to be replicated, telomeres become progressively shorter owing to the so-called "end replication problem" [31, 32]. Thus, telomere shortening occurs associated with increasing age in humans [33], mice [34] and other species, and the rate of telomere shortening has been shown to correlate with species lifespan [35]. When telomeres become critically short this results in loss of telomere protection, leading to activation of a persistent DNA damage response [36] and loss of cellular viability by induction of apoptosis and/or senescence [30].

Telomerase is a reverse transcriptase that is able to elongate telomeres de novo by adding TTAGGG repeats to chromosome ends [37]. Telomerase is active in embryonic stem cells, thereby ensuring sufficiently long telomeres with generations in a given species. After birth, however, telomerase expression is silenced in the majority of cell types causing telomeres to shorten with age.

We have shown by using telomerase-deficient mice with critically short telomeres, that short telomeres are sufficient to impair the ability of stem cells to regenerate different tissues, including skin, brain and bone marrow [38-41]. In humans, mutations in telomerase or telomere-binding proteins can also lead to very short telomeres and appearance of pathologies characterized by loss of the regenerative capacity of tissues and presence of fibrosis in lungs, liver or kidney, as well as by intestinal atrophy and bone marrow aplasia [42].

In particular, we previously demonstrated that short or dysfunctional telomeres are at the origin of pulmonary fibrosis in mouse models of the disease [43]. In particular, induction of telomere dysfunction specifically in alveolar type II (ATII) cells by deletion of an essential telomere protective protein in these cells, TRF1, is sufficient to induce progressive and lethal pulmonary fibrosis phenotypes in mice, which are concomitant with induction of telomeric DNA damage, cell death and senescence [43]. These findings demonstrate that dysfunctional telomeres in lungs ATII cells lead to loss of viability of these cells and induction of fibrosis. Also in support of this notion, we have demonstrated that therapies aimed to elongate telomeres, such as a telomerase gene therapy using adeno-associated vectors (AAV9-TERT) can stop the progression of pulmonary fibrosis associated to short telomeres in mouse models of the disease by increasing telomere length in ATII cells, as well as their proliferative potential [44], thus demonstrating the importance of sufficiently long telomeres to allow tissue regeneration.

Importantly, as SARS-CoV-2 infects different cell types in humans, including ATII cells in the lungs, it is plausible that viral infection could damage these different cell types forcing an increased turn-over of different regenerative cell types. While in young individuals with sufficiently long telomeres, regenerative cell types, such as lung ATII cells could undergo these extra cell divisions and contribute to tissue healing, older individuals with shorter telomeres may fail to allow cell proliferation and regeneration, thus leading to tissue failure. Thus, here we set to assess whether telomere length in COVID-19 patients correlated with development of more severe COVID-19 pathologies.

\section{RESULTS}

\section{Pathologies in COVID-19 patient cohort}

In order to assess the potential impact of telomere length on pathologies associated to COVID-19 disease, we obtained both DNA and mononuclear cells from peripheral blood samples from patients hospitalized at the IFEMA field hospital in Madrid, which was constructed to treat COVID-19 patients. A total of 61 female and 28 male patients of ages ranging from 29 to 85 years old were included in the study (Table 1). The patient cohort had different severity of pathologies and received the treatments indicated in Table 1. None of the patients included in this study died as a consequence of the COVID-19 disease.

In order to correlate patient severity with telomere length, we first grouped the patients according the a severity score ranging from 1 to 4 , with severity score 1 in the case of patients with low fever and cough but without any radiological features of pneumonia to patients with severity score of 4 in the cases of patients with features of Acute Respiratory Distress Syndrome (ARDS) requiring mechanical ventilation along with presence of multiorgan dysfunction failure, metabolic acidosis and coagulation dysfunction (Materials and Methods). 
Table 1. Patients included in this study.

\begin{tabular}{|c|c|c|c|}
\hline Age & Sex & COVID-19 severity & Treatment \\
\hline 29 & Male & Moderate & Hydroxychloroquine, Azitromicine \\
\hline 30 & Female & Moderate & Dolquine, Azitromicine \\
\hline 31 & Female & Moderate & Hydroxychloroquine, Azitromicine, Kaletra \\
\hline 33 & Female & Moderate & Hydroxychloroquine, Azitromicine \\
\hline 33 & Female & Severe & Hydroxychloroquine, Azitromicine \\
\hline 35 & Male & Moderate & Hydroxychloroquine, Ceftriaxone, Azitromicine, Kaletra \\
\hline 36 & Female & Acute & Hydroxychloroquine, Kaletra, Corticoids, Ceftriaxone, Azitromicine, LINEZOLID \\
\hline 38 & Female & Mild & Hydroxychloroquine \\
\hline 39 & Female & Moderate & Hydroxychloroquine, Azitromicine \\
\hline 40 & Male & Severe & Hydroxychloroquine, Azitromicine,Ceftriaxone, systemic corticoids \\
\hline 41 & Female & Moderate & Hydroxychloroquine, Kaletra \\
\hline 42 & Male & Severe & Hydroxychloroquine, Kaletra, Corticoids \\
\hline 43 & Female & Mild & Hydroxychloroquine, Azitromicine \\
\hline 43 & Female & Severe & Hydroxychloroquine, Azitromicine, Corticoids, Kaletra, Tocilizumab \\
\hline 43 & Female & Moderate & Hydroxychloroquine, Azitromicine \\
\hline 44 & Male & Mild & Hydroxychloroquine \\
\hline 45 & Female & Moderate & Dolquine, Kaletra, Azitromicine \\
\hline 45 & Female & Severe & Kaletra, Hydroxychloroquine, Azitromicine, Corticoids \\
\hline 46 & Female & Moderate & Kaletra, Dolquine, Colchicine \\
\hline 46 & Female & Severe & Dolquine, Kaletra, Azitromicine, Corticoids \\
\hline 46 & Female & Severe & Hydroxychloroquine, Azitromicine \\
\hline 47 & Female & Moderate & Hydroxychloroquine \\
\hline 47 & Male & Severe & Hydroxychloroquine, Azitromicine, systemic corticoids \\
\hline 47 & Female & Mild & Hydroxychloroquine,Ceftriaxone \\
\hline 48 & Male & Severe & Hydroxychloroquine, Azitromicine, Tocilizumab, Kaletra \\
\hline 49 & Female & Moderate & Hydroxychloroquine, Azitromicine \\
\hline 49 & Male & Severe & Hydroxychloroquine, Azitromicine, systemic corticoids, Tocilizumab \\
\hline 49 & Male & Moderate & Hydroxychloroquine, Azitromicine \\
\hline 49 & Male & Moderate & Hydroxychloroquine, Azitromicine,Ceftriaxone \\
\hline 49 & Male & Moderate & Hydroxychloroquine, Kaletra \\
\hline 49 & Female & Moderate & Hydroxychloroquine, Azitromicine \\
\hline 50 & Female & Moderate & Hydroxychloroquine, Azitromicine \\
\hline 51 & Male & Severe & Hydroxychloroquine, Azitromicine \\
\hline 51 & Female & Moderate & Hydroxychloroquine, Azitromicine, Kaletra,Ceftriaxone \\
\hline 51 & Female & Moderate & Hydroxychloroquine, Kaletra, Azitromicine, Corticoids \\
\hline 52 & Female & Severe & Chloroquine, Kaletra, Tocilizumab, methylprednisolone \\
\hline 52 & Male & Severe & Hydroxychloroquine \\
\hline 52 & Female & Moderate & Hydroxychloroquine, Azitromicine \\
\hline 53 & Female & Severe & Hydroxychloroquine, Corticoids, Tocilizumab \\
\hline 53 & Male & Moderate & Hydroxychloroquine, Azitromicine \\
\hline 53 & Male & Severe & Hydroxychloroquine, Azitromicine, Cortocoid therapy \\
\hline 54 & Female & Acute & $\begin{array}{c}\text { Hydroxychloroquine, Kaletra, Azitromicine, INTERFERON, Tocilizumab, } \\
\text { Corticoids }\end{array}$ \\
\hline 54 & Female & Acute & Hydroxychloroquine, Azitromicine, systemic corticoids, Tocilizumab \\
\hline 54 & Female & Severe & Hydroxychloroquine, Azitromicine, Kaletra, systemic corticoids \\
\hline 54 & Female & Severe & Hydroxychloroquine, Azitromicine, Corticoids, Tocilizumab \\
\hline 54 & Female & Moderate & Hydroxychloroquine \\
\hline 54 & Female & Moderate & Hydroxychloroquine, Azitromicine,Ceftriaxone \\
\hline
\end{tabular}




\begin{tabular}{|c|c|c|c|}
\hline 54 & Female & Moderate & Hydroxychloroquine, Kaletra, Azitromicine \\
\hline 55 & Female & Mild & Hydroxychloroquine \\
\hline 55 & Female & Mild & Ceftriaxone, Hydroxychloroquine \\
\hline 55 & Male & Moderate & Hydroxychloroquine \\
\hline 56 & Female & Moderate & Dolquine, Azitromicine \\
\hline 56 & Female & Severe & Hydroxychloroquine, Azitromicine, systemic corticoids \\
\hline 56 & Male & Moderate & Hydroxychloroquine, Azitromicine \\
\hline 56 & Female & Severe & REMDESIVIR, Corticoids, Tocilizumab \\
\hline 57 & Male & Severe & Chloroquine, Corticoids, Interferon beta \\
\hline 57 & Male & Acute & Hydroxychloroquine, Azitromicine, Corticoids, Tocilizumab \\
\hline 57 & Female & Severe & Hydroxychloroquine, Kaletra, Corticoids \\
\hline 57 & Male & Moderate & Hydroxychloroquine, Kaletra \\
\hline 57 & Female & Severe & Hydroxychloroquine, Corticoids, Tocilizumab, Azitromicine \\
\hline 58 & Male & Severe & Hydroxychloroquine, Azitromicine, systemic corticoids \\
\hline 58 & Female & Moderate & Hydroxychloroquine+Azitromicine \\
\hline 58 & Female & Severe & Hydroxychloroquine, Azitromicine, Methylprednisone \\
\hline 59 & Female & Severe & Hydroxychloroquine, Azitromicine, Corticoids \\
\hline 59 & Female & Moderate & Hydroxychloroquine, Kaletra, Predisolone \\
\hline 60 & Female & Severe & Hydroxychloroquine, Azitromicine, Corticoids, Tocilizumab \\
\hline 60 & Female & Moderate & Hydroxychloroquine+Azitromicine+Kaletra \\
\hline 61 & Female & Moderate & Dolquine, Azitromicine \\
\hline 61 & Male & Severe & Hydroxychloroquine, Ceftriaxone, Azitromicine, systemic corticoids \\
\hline 62 & Female & Moderate & Hydroxychloroquine, Azitromicine \\
\hline 62 & Female & Severe & Hydroxychloroquine, Azitromicine, Kaletra \\
\hline 63 & Female & Severe & Hydroxychloroquine, Azitromicine, Dexamethasone \\
\hline 63 & Male & Severe & Hydroxychloroquine, Azitromicine, Corticoids \\
\hline 65 & Male & Severe & Hydroxychloroquine, Kaletra, Corticoids \\
\hline 65 & Male & Severe & Hydroxychloroquine, Azitromicine, Kaletra, Dexamethasone, Tocilizumab \\
\hline 66 & Female & Severe & Hydroxychloroquine, Kaletra, systemic corticoids \\
\hline 67 & Female & Moderate & Hydroxychloroquine \\
\hline 67 & Female & Severe & Chloroquine, Kaletra, Azitromicine, Tocilizumab, Corticoids \\
\hline 67 & Male & Severe & Hydroxychloroquine, Azitromicine, Corticoids, Kaletra \\
\hline 69 & Male & & \\
\hline 70 & Female & Severe & Dolquine, Kaletra, Azitromicine, Corticoids \\
\hline 71 & Male & Severe & Hydroxychloroquine, Kaletra, Corticoids \\
\hline 71 & Female & Severe & Hydroxychloroquine, Azitromicine, Cortocoid therapy \\
\hline 72 & Female & Acute & Hydroxychloroquine, Azitromicine, systemic corticoids \\
\hline 73 & Female & Severe & Hydroxychloroquine, Azitromicine, Kaletra, systemic corticoids, Tocilizumab \\
\hline 74 & Female & Severe & Hydroxychloroquine, Azitromicine, Corticoids \\
\hline 77 & Female & Severe & Hydroxychloroquine \\
\hline 81 & Female & Mild & Hydroxychloroquine, Azitromicine,Ceftriaxone \\
\hline 85 & Female & Moderate & Hydroxychloroquine, Kaletra, Azitromicine \\
\hline
\end{tabular}

\section{Determination of telomere length in COVID-19 patients}

In order to determine telomere length in our patient cohort, peripheral blood was extracted from the arm from the different patients and used to measure telomere length by three independent techniques (Materials and Methods).
First, we determined telomere length in DNA extracted from peripheral blood by using both the Southern blotting-based Telomere Restriction Analysis (TRF; see [38]) and the quantitative-PCR (qPCR) telomere length analyses [45]. In addition to these two technologies based on DNA samples, we also measured telomere length on fresh peripheral blood mononuclear cells by using the 
more precise high- throughput quantitative fluorescence in situ hybridization (HT Q-FISH) previously described by us $[34,35,46]$, which allows determination of individual telomere fluorescence signals using tens of thousands of cells from a single patient. The fact that HT Q-FISH can determine individual telomere fluorescence spots in interphasic nuclei, each spot usually formed by several clustered telomeres, allows to the determine the abundance of very short telomeres.

We observed a very significant correlation between the telomere length measurements obtained by the three different techniques (Figure 1A), thus indicating the robustness of the data on telomere length obtained in our patient cohort. Given the good correlation of the telomere length data obtained with the three technologies, we decided to perform the rest of the analysis with the telomere length data obtained by HT Q-FISH, as it measures telomeres in a single cell manner and it also allows to measure individual telomere spots within single nuclei.

The rate of telomere shortening in the patient cohort was of $77 \mathrm{bp} /$ year (Figure 1B). This rate of telomere shortening is in the range previously published by us and others [45-48]. In agreement with telomere shortening with increasing patient age, we also observed an increase in the abundance of short telomeres

\section{A}

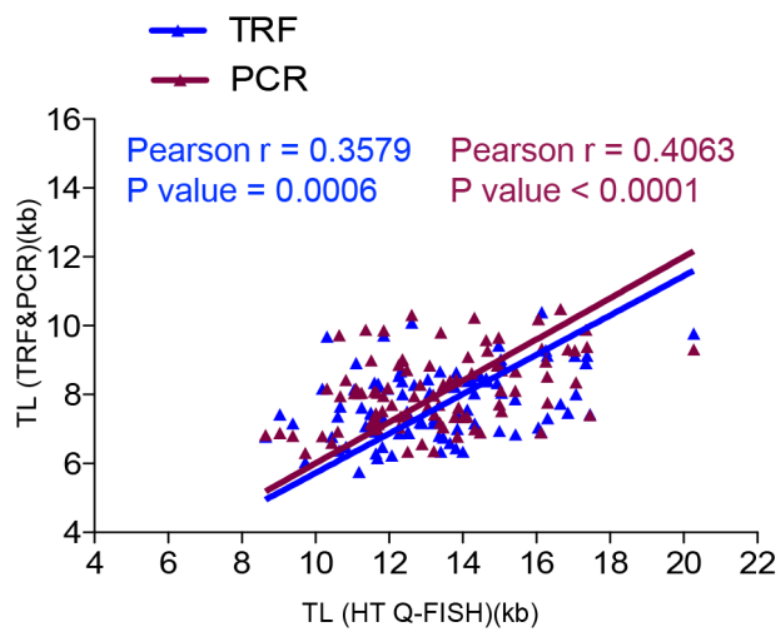

B

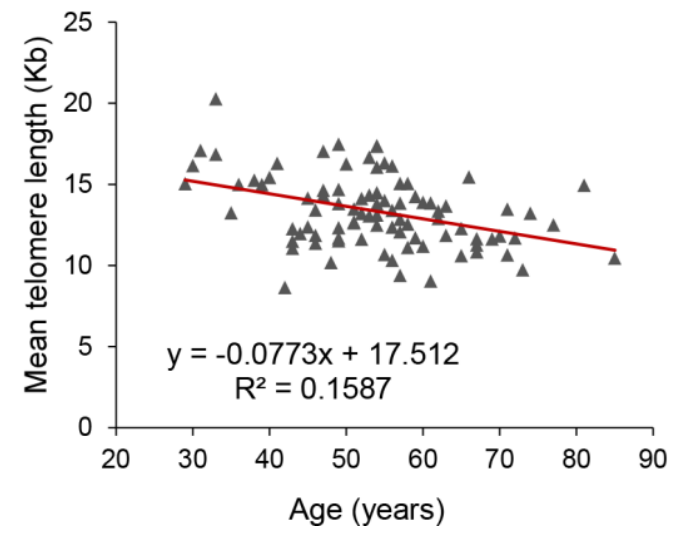

C

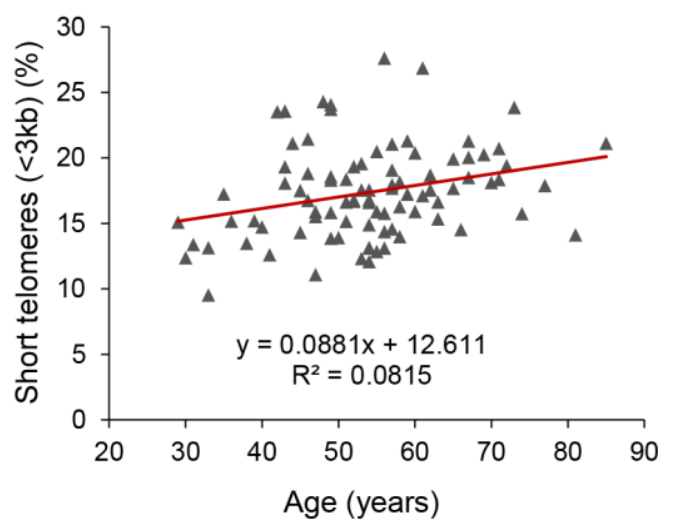

Figure 1. Correlation between HT Q-FISH and PCR and TRF techniques for telomere length measurements. (A) Correlation of telomere length measured by TRF, qPCR and HT Q-FISH in Peripheral blood mononuclear cell (PMBC) samples from 89 individuals. (B, C) Linear regression analysis was used to determine the rate of telomere shortening $(\mathbf{B})$ and the rate of the increase of short telomeres $(<3 \mathrm{~kb})$ (C) per year in PMBCs. The telomere length data in (B, C) correspond to HT-qFish analysis. The Pearson correlation coefficient and linear regression equation were determined using GraphPad Software. 
(ie, telomere fluorescence spots corresponding to less than $3 \mathrm{~kb}$ of telomere length) which increased at a rate of $8.8 \%$ per year (Figure 1B).

When we analyzed the data segregated by gender, linear regression of telomere length data in COVID-19 female patients showed that their telomeres were consistently longer than those of male patient at all age ranges, as well as they showed a lower percentage of short telomeres compared to male patients (Figure 2A-2D), also in agreement with previous findings [46]. Again, when segregated by gender, the rates of telomere shortening were in a range of 70-80 bp/year (Figure 2A). Similarly, the increase in the percentage of short telomeres with age was also similar in both genders (Figure 2A, 2B).

The fact that COVID-19 female patients had longer telomeres than men patients at different age ranges is in line with the fact that female COVID-19 patients show a lower mortality than males (see COVID-19 Sex-Disaggregated Data Tracker available at: http://globalhealth5050.org/covid19).

\section{Age and telomere length correlate with COVID-19 severity}

In order to assess whether short telomeres correlated with the severity of COVID-19 disease, we used a Pearson correlation analysis between the mean telomere length or the percentage of short telomeres $(<3 \mathrm{~kb})$ as determined by the HT Q-FISH technique, and either age or the severity score of the different COVID-19 patients ranging from 1 (less severe) to 4 (more severe) (see Materials and Methods).

As expected, we observed a significant inverse correlation between mean telomere length (TL) and age of the COVID-19 patients ( $\mathrm{r}=-0.3985$; $\mathrm{p}=0.0001$; Figure $3 \mathrm{~A})$. We also observed a significant direct correlation between percentage of short telomeres (ie, telomeres < $3 \mathrm{~Kb})$ and patient age $(\mathrm{r}=0.285 ; \mathrm{p}=0.0067$; Figure $3 \mathrm{~B})$. Thus, these findings confirm a significantly higher incidence of short telomeres with increasing age in the COVID-19 patients. We also observed an inverse correlation between mean telomere length (TL) and the severity score of the COVID-19 patients when using HT Q-FISH ( $r=-0.1752 ; \mathrm{p}=0.1026$; Figure 3A) and a direct correlation between the percentage of short telomeres (ie, telomeres $<3 \mathrm{~Kb})$ and the severity score $(\mathrm{r}=0.1454$; $\mathrm{p}=0.1766$; Figure 3B), although these correlations did not reach statistical significance. To further analyze this, we performed similar analysis with the telomere length data obtained by TRF and by PCR (Figure 3C, 3D). Again, we confirmed a significant inverse correlation between mean telomere length (TL) and age of the COVID-19 patients by TRF ( $\mathrm{r}=-0.4675 ; \mathrm{p}<0.0001$; Figure 3C) as well as by PCR ( $r=-0.405 ; \mathrm{p}=0.0001$; Figure 3D) techniques. Importantly, by these two DNAbased techniques, the correlation between telomere length and COVID-19 severity reached statistical significance (TRF: $r=-0.3119, p=0.004$; Figure 3C; PCR: $r=-0.2308, p=0.036$; Figure 3D.

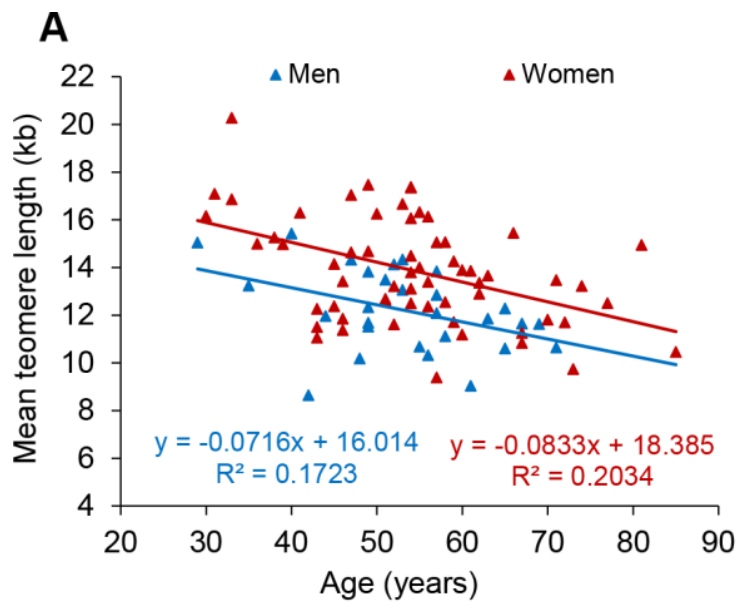

Decrease of mean telomere length Men (n=28) 72 bp/year Women $(n=61) 83$ bp/year
B

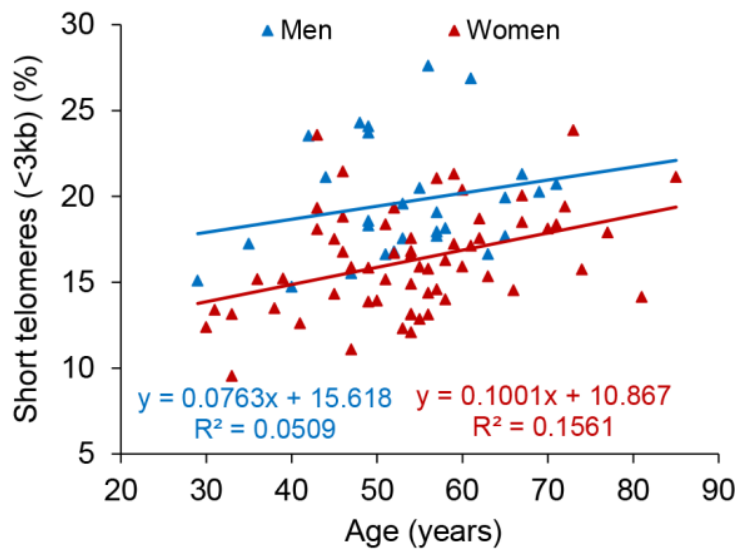

Increase in percentage of short telomeres Men $(n=28) 7.6 \%$ Women $(n=61) 10 \%$

Figure 2. Telomere shortening and of increase in short telomeres with age in men and women. (A, B) Percentage of short telomeres (<3 kb) in PMBC samples. Mean telomere length (A) and percent of short telomeres (<3kb) (B) in PMBCs from male (blue) and female (red) patients. Linear regression analysis was used to assess the rate of telomere shortening expressed as number of bp loss and the increase of the percentage of short telomeres per year. 
Finally, we also observed a significant direct correlation between age of the COVID-19 patients and the severity score of the disease $(r=0.2299 ; \mathrm{p}=0.0312$; Figure 4A, 4B). Furthermore, we observed an inverse correlation between age and mean telomere length (TL) and a direct

A

HT Q-FISH

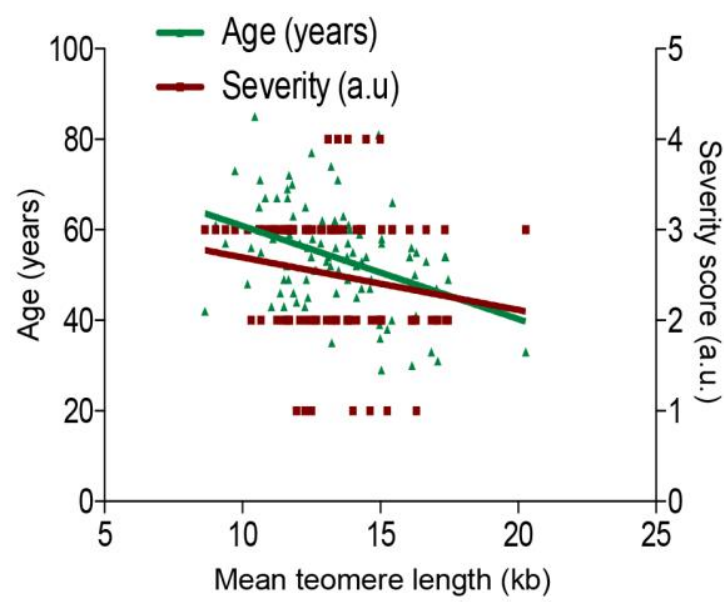

Pearson $r=-0.3985$ Pearson $r=-0.1752$

$P$ value $=0.0001 \quad P$ value $=0.1026$

C

TRF

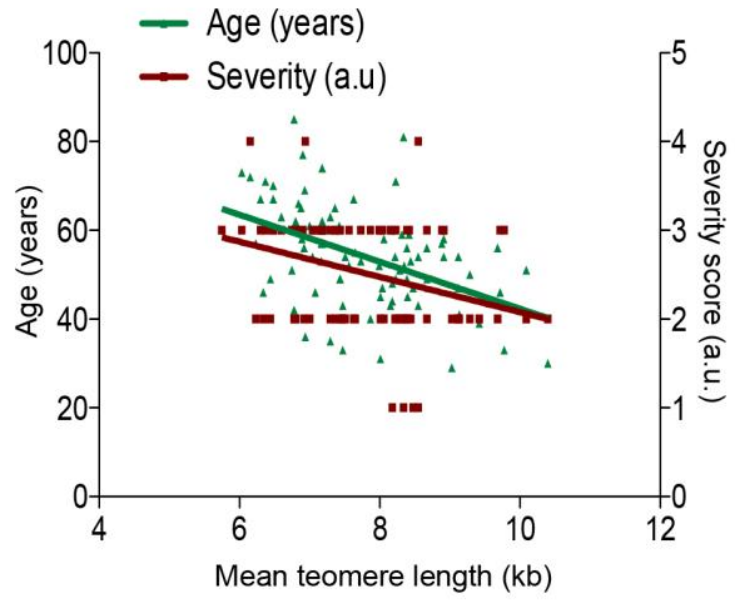

$\begin{array}{ll}\text { Pearson } r=-0.4675 & \text { Pearson } r=-0.3119 \\ P \text { value }<0.0001 & P \text { value }=0.004\end{array}$ correlation between age and the percentage of short telomeres when using HT Q-FISH (Figure 4A, 4B).

Together, these findings suggest significant correlations of age as well as telomere length with COVID-19 severity.

B

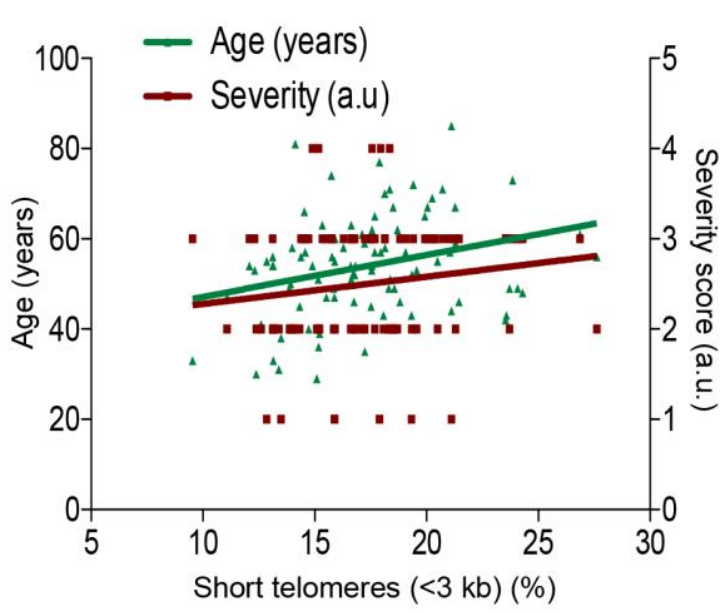

Pearson $r=0.285$ Pearson $r=0.1454$

$P$ value $=0.0067 \quad P$ value $=0.1766$

D

PCR

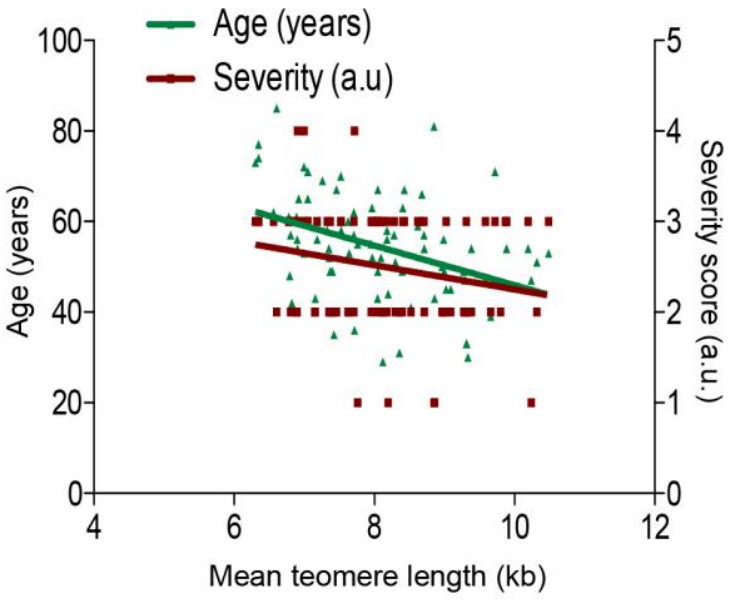

$\begin{array}{ll}\text { Pearson } r=-0.405 & \text { Pearson } r=-0.2308 \\ P \text { value }=0.0001 & P \text { value }=0.036\end{array}$

Figure 3. Correlation between telomere length, age and COVID-19 severity. (A-D) Pearson correlation analysis between telomere length (A, C, D) or percentage of short telomeres (<3 kb) (B) and age or COVID-19 severity in PMBC samples. In (A, B) telomere length was analysed by HT-QFISH and in (C, D) by TRF and PCR, respectively. The severity score was established by assigning values of $1,2,3,4$ for mild, moderate, severe, and acute, respectively (see Materials and Methods). The Pearson $r$ coefficient and the $P$ values are indicated. 
Higher severity of COVID-19 disease in patients in the lower percentiles of telomere length

The findings suggest that COVID-19 patients with shorter telomere length may have a higher risk of more severe pathologies. To further test this, we divided the patients in quartiles according to either their mean telomere length or their percentage of short telomeres using the telomere signal fluorescence data obtained by HT Q-FISH. We observed that patients in the lower quartile of mean telomere length $(<25 \%)$ had a higher severity score $(\mathrm{p}=0.06$; Figure $5 \mathrm{~A})$. Similarly, the

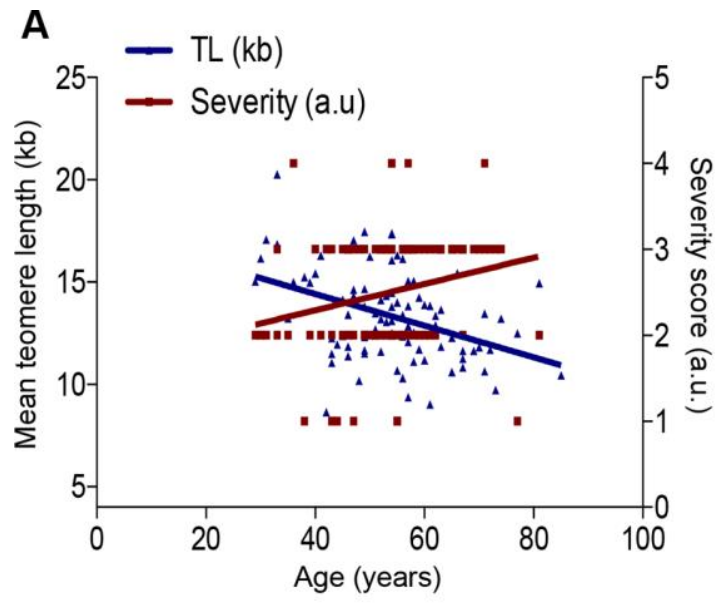

Pearson $r=-0.3985$ Pearson $r=0.2299$

$P$ value $<0.0001 \quad P$ value $=0.0312$
B

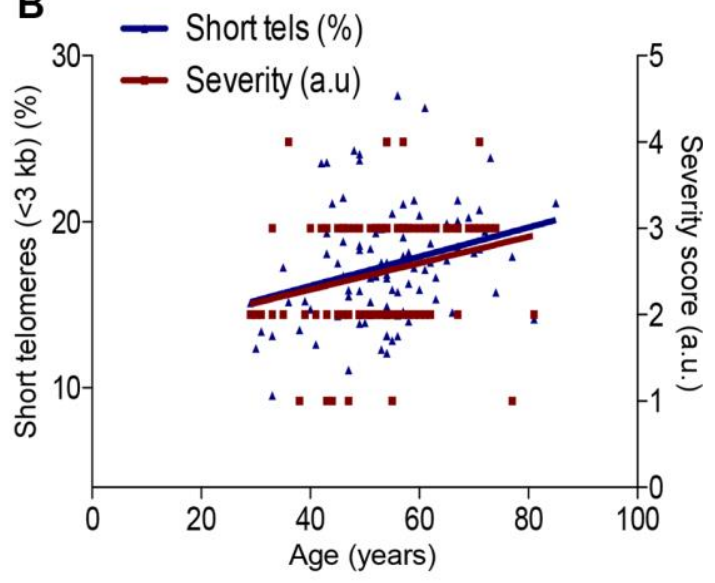

Pearson $r=0.2855 \quad$ Pearson $r=0.2299$

$P$ value $=0.0067 \quad P$ value $=0.0312$

Figure 4. Correlation between age and COVID-19 severity and telomere length. (A, B) Person correlation analysis between age and telomere length measured by HT Q-FISH in PMBC samples $(\mathbf{A})$ and with percentage of short telomeres $(<3 \mathrm{~kb})$. The severity score was established by assigning values of 1, 2, 3, 4 for mild, moderate, severe and acute, respectively (see Materials and Methods). The Pearson $r$ coefficient and the $P$ values are indicated.

A

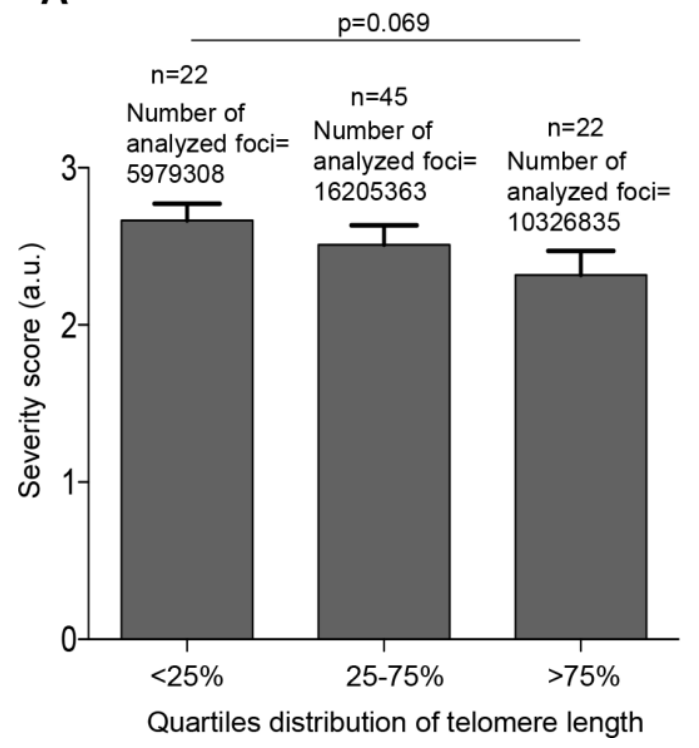

B

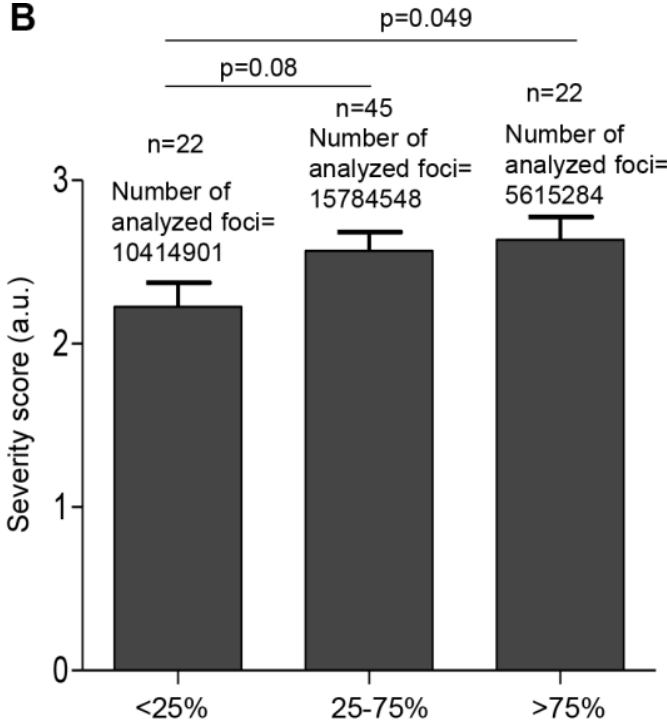

Quartiles distribution of short telomeres

Figure 5. Patients with shorter telomeres develop more severe COVID-19 disease. (A) The telomere lengths of patients were distributed into the quartiles $<25 \%$ ( $<11.68 \mathrm{~kb}), 25-75 \%(11.68-14.96 \mathrm{~kb})$ and $>75 \%(>14.96 \mathrm{~kb})$ and correlated with COVID-19 severity. (B) The abundance of short telomeres was distributed into the quartiles $<25 \%(<14.73 \%), 25-75 \%(14.73-19.32 \%)$ and $>75 \%(>19.32 \%)$ and correlated with COVID-19 severity. Data represent mean values \pm SEM. Statistical significance was assessed using Student's t test. 
patients in the higher quartile of percentage of short telomeres had significantly higher severity scores of the disease ( $\mathrm{p}=0.049$; Figure 5B).

\section{Different rates of telomere shortening in patients with different severity scores}

As patients in the lower quartile of telomere length have a significantly higher risk of severe COVID-19 pathologies, we set to investigate whether the rates of telomere shortening in higher severity score patients

A

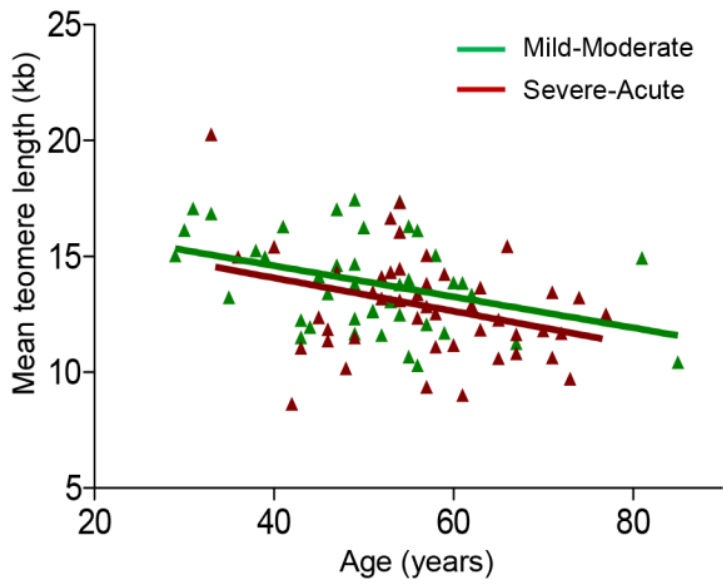

Decrease of mean telomere length

Mild-Moderate $(n=39) 67+/-25$ bp/year, $r=0.145$

Severe-Acute $(n=44) 72+/-31$ bp/year, $r=0.1067$

$\mathrm{P}=0.024$

C

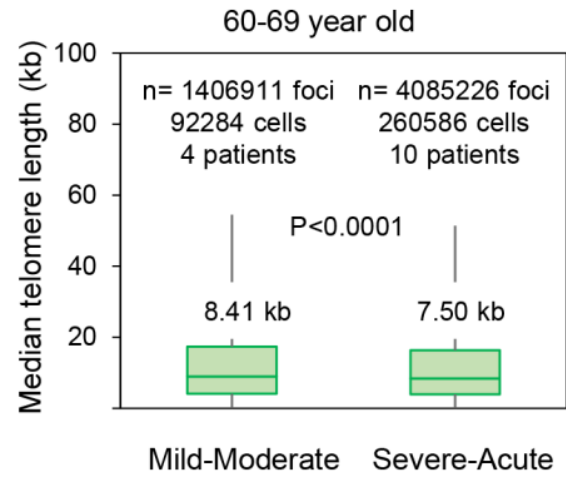

were significantly higher than in the lower severity score patients. To this end, we pooled together the patients in "mild-moderate" and "severe-acute" severity groups. We found that patients with a "severe-acute" diagnosis showed a significantly faster rate of telomere shortening compared to the "mild-moderate" diagnosis as determined by HT Q-FISH ( $\mathrm{p}=0.024$; Figure 6A). Of note, patients with "severe-acute" COVID-19 disease have shorter telomeres along all age groups compared to patients with "mild-moderate" COVID-19 disease. Similarly, we found an increased rate of accumulation

\section{B}

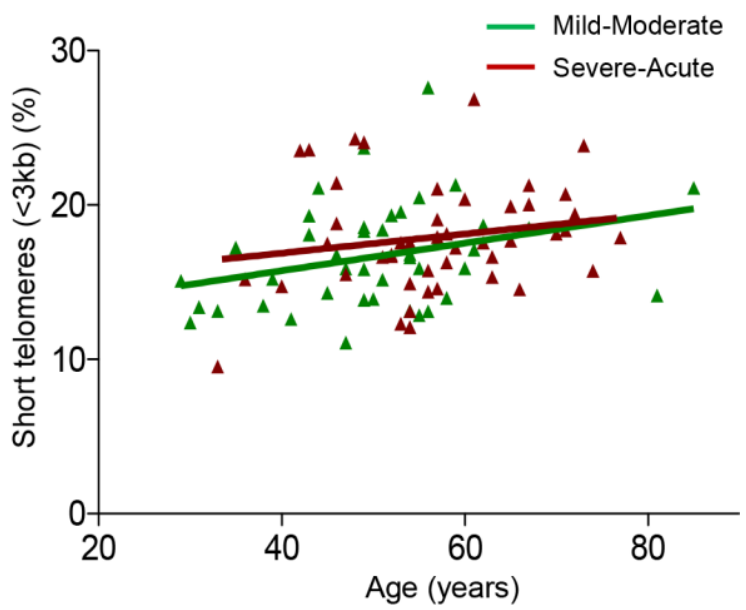

Increase in percentage of short telomeres ( $<3 \mathrm{~kb})$

Mild-Moderate $(n=39) 8.9 \%+/-4.4 \%, r=0.092$

Severe-Acute $(n=44) 6.2 \%+/-5,1 \%, r=0.032$

$\mathrm{P}=0.08$

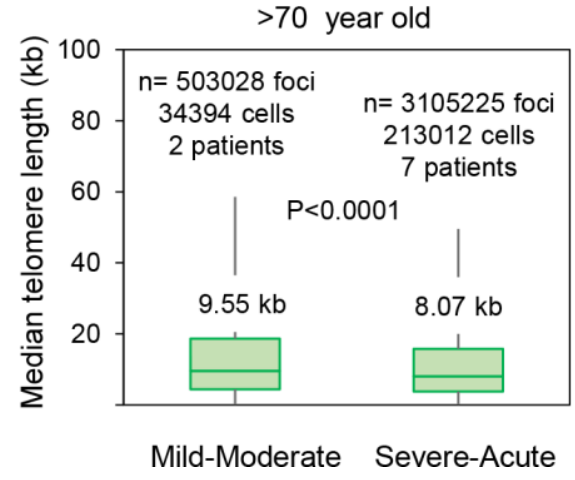

Figure 6. Patients with a higher COVID-19 severity score show faster telomere shortening rates. (A, B) Telomere shortening (A) and increase in percent of short telomeres $(<3 \mathrm{~kb})(\mathbf{B})$ with age in patients diagnosed with mild-moderate and severe-acute COVID-19. Linear regression analysis was used to assess the number of bp loss and of the percent of short telomeres per year ( $<3 \mathrm{~kb})$ in PMBC of these donors. Statistical significance was assessed using the Mann-Whitney test. (C) Whisker plot representation of telomere length. The between 60-69 and older than 70-year-old were pooled together within the same age group. The patients diagnosed with mild or moderate and those diagnosed with severe or acute were grouped. The telomere length corresponding to individual telomere foci were plotted according to Covid-19 severity groups. The ends of the box are the upper and lower quartiles so that the box spans the interquartile range. The middle line represents the median and bars to standard deviation. The statistical significance was calculated by one way Anova with post tukey test. $\mathrm{n}=$ number of foci. 
of short telomeres in patients with a "severe-acute" diagnosis compared to patients with a "mild-moderate" severity score $(\mathrm{p}=0.08$; Figure $6 \mathrm{~B})$.

In order to address whether this association between Covid-19 severity and short telomeres was independent of the age, we grouped the patients in different age groups (below 40 years of age; between 40-49; 50-59; 60-69 and over 70 years of age) and compared the fluorescence of individual telomere foci in patients showing either "mild-moderate" or "severe-acute" COVID-19 severity. We found that for age groups above 60 years of age, telomeres were shorter in the groups with "severe-acute" severity compared to "mildmoderate" severity (Figure 6C).

\section{DISCUSSION}

Data from COVID-19 around the world shows that patients of older age groups show a higher severity of the disease and a higher mortality. Male patients also show a higher mortality than female patients (see COVID-19 Sex-Disaggregated Data Tracker available at: http://globalhealth5050.org/covid19). This suggest that molecular mechanisms of aging maybe aggravating the pathological consequences of infection by the SARS-CoV-2 virus. Telomere shortening and accumulation of DNA damage steaming from short telomeres has been proposed as one of the primary hallmarks of aging [27]. In particular, short telomeres are known to result in chromosomal instability and loss of cell viability by inducing replicative senescence and/or apoptosis [26]. Importantly, by using mouse models that lack telomerase activity, we and others have shown that short telomeres impair the regenerative capacity of tissues leading to loss of tissue homeostasis and degenerative diseases [40]. Similarly, humans with critically short telomeres owing to mutations in telomerase also show an impaired regeneration capacity and are at a higher risk of developing degenerative diseases in both low proliferative (lung, kidney) and high proliferative tissues (bone marrow, skin) [42].

Given that the SARS-CoV-2 virus infects different cell types in the organisms, including regenerative cell types such as alveolar type II (ATII) cells in the lungs [8-13, 49], here we hypothesize that individuals with short telomeres would have an impaired regenerative response upon SARS-CoV-2 infection, thus leading to more severe and progressive pathologies, such as fibrosis-like pathologies in the lungs, kidney or liver.

To address this, we have measured telomere length in a total of 89 patients diagnosed with COVID-19 ranging from mild to acute disease. As expected we found that telomere length decreases with age, with women having longer telomeres than men at different age groups, which could explain why COVID-19 disease is more severe in males than females. Interestingly, we also found that those patients that have more severe COVID19 pathologies have shorter telomeres at different ages compared to the patients with milder disease. Indeed, patients which are in the lower percentile of telomere length also have significantly higher severity scores.

These findings demonstrate that molecular hallmarks of aging, such as presence of short telomeres can influence the severity of COVID-19 pathologies. As short telomeres can be elongated by telomerase, and telomerase activation strategies have been shown by us to delay aging and age related pathologies [50], as well as to have therapeutic effects in diseases associated to short telomeres, such as pulmonary fibrosis [44], it is tempting to speculate that such telomerase activation therapies could ameliorate some of the tissue pathologies remaining in COVID-19 patients, such as fibrosis-like pathologies in the lungs [51] after overcoming the viral infection.

\section{MATERIALS AND METHODS}

\section{Patients}

In this study participated a total of 89 patients $(61$ female and 28 male patients of ages ranging from 29 to 85 years old) from the IFEMA field hospital installed due to the emergency situation in Madrid, Spain. All these samples were donated to CNIO BioBank which allows their use for biomedical analyses under the existing law requirements in Spain.

\section{Blood samples}

A total of $8 \mathrm{ml}$ of blood were collected from the arm of each patient in heparin tubes and $4 \mathrm{ml}$ in EDTA tubes and shipped within less than $24 \mathrm{~h}$ to the DNA National Bank at Salamanca University, where they were immediately processed at a biosafety level (BSL) 3 (BSL-3) biocontainment level. Peripheral blood mononuclear cells (PBMCs) were purified by Ficoll gradient and frozen in $90 \%$ FBS (v/v) supplemented with $10 \%(\mathrm{v} / \mathrm{v})$ DMSO into a number of aliquots ranging from 1 to 3 , according to cell number. PBMCs were stored in vapor phase-nitrogen.

Genomic DNA was extracted directly from blood samples using the Real Blood DNA Kit and stored longterm in $\mathrm{TE}$ at $-20^{\circ} \mathrm{C}$.

\section{Q-PCR Assay to measure average telomere length}

Telomere length was measured in genomic DNA isolated from blood samples. We used a modified 
monochrome multiplex quantitative polymerase chain reaction (PCR) method already described [45]. Briefly, each reaction included SYBR Green I (Promega), telomere primer pair telg (5'-ACACTAAGGTTTGG GTTTGGGTTTGGGTTTGGGTTAGTGT-3') and telc (5'-TGTTAGGTATCCCTATCCCTATCCCTATCCCT ATCCCTAACA-3') (final concentrations 900nM each), albumin primer pair albu (5'-CGGCGGCGGGCGGCG CGGGCTGGGCGGaaatgctgcacagaatcettg-3') and albd (5'-GCCCGGCCCGCCGCGCCCGTCCCGCCGgaaaag catggtcgcctgtt-3') (final concentrations $900 \mathrm{nM}$ each) and $20 \mathrm{ng}$ of genomic DNA. The Applied Biosystems QuantStudio 6 Flex Real-Time PCR System was used. The thermal cycling profile was Stage 1: $15 \mathrm{~min}$ at $95^{\circ} \mathrm{C}$; Stage 2: 2 cycles of $15 \mathrm{~s}$ at $94^{\circ} \mathrm{C}, 15 \mathrm{~s}$ at $49^{\circ} \mathrm{C}$; and Stage 3: 32 cycles of $15 \mathrm{~s}$ at $94^{\circ} \mathrm{C}, 10 \mathrm{~s}$ at $62^{\circ} \mathrm{C}, 15$ $\mathrm{s}$ at $74^{\circ} \mathrm{C}$ with signal acquisition, $10 \mathrm{~s}$ at $84^{\circ} \mathrm{C}, 15 \mathrm{~s}$ at $88^{\circ} \mathrm{C}$ with signal acquisition. To serve as a reference for standard curve calculation, HeLa cells were serially diluted and qPCR performed as described above. After thermal cycling was completed, the QuantStudio 6 software was used to generate standard curves and $\mathrm{Ct}$ values for telomere signals and reference gene signals. The average telomere length was termed $\mathrm{T} / \mathrm{S}$ ratio. Finally, T/S ratios were converted into $\mathrm{kb}$ by external calibration with the K562 (6.5 kb), CCRF-CEM (7.5 $\mathrm{kb}$ ), Jurkat (11.5 kb) and HeLa1211 (24 kb) cell lines.

\section{Terminal restriction fragment analysis}

Mean telomere length by Telomere Restriction Fragment (TRF) was determined using the method already described [38]. Briefly, genomic DNA was digested by MboI and separated by gel electrophoresis in $0.5 \mathrm{X}$ TBE maintained at $14^{\circ} \mathrm{C}$, using a CHEF DR-II pulsed-field apparatus (BioRad) for $14 \mathrm{~h}$ at $5 \mathrm{~V} / \mathrm{cm}$ at a constant pulse time of $0.5 \mathrm{~s}$. The gel was transferred to a nylon membrane (Hybond-XL, GE Healthcare) and probed with a ${ }^{32} \mathrm{P}$-labeled telomeric probe (TTAGGG)n (a gift from T. de Lange). Mean TRF lengths were determined using an ImageQuant TL.

\section{HT Q-FISH}

Clear bottom black-walled 96-well plates (Greiner, Longwood, FL) were precoated with a $0.001 \%$ (wt/vol) poly-L-lysine solution (Sigma-Aldrich, St. Louis, MO) for $1 \mathrm{~h}$ at $37^{\circ} \mathrm{C}$. Poly-L-lysine was removed and wells rinsed with RPMI before cell addition (75,000-150000 lymphocytes/well).

PBMCs were thawed in complete RPMI 1640 growth media supplemented with $10 \%$ FBS (v/v) and seeded at a concentration of 100000 cells/ well in triplicate wells per sample. Cells were left to adhere to the plate for $1 \mathrm{~h}$ at $37 \mathrm{C}$ in incubator with $95 \%$ humidity, $5 \% \mathrm{CO}_{2}$. Plates were then removed from incubator and then fixed at room temperature (RT) by slowly filling up the wells with $200 \mathrm{ul}$ methanol/acetic acid (3/1, vol/vol) and incubated for 10 to $15 \mathrm{~min}$. The solution was removed, and this was repeated 2 more times, leaving the last fixative volume up for a total of $1 \mathrm{~h}$ fixation. Plates were then moved to -20 until processed for highthroughput quantitative FISH (HT Q-FISH).

We performed HT Q-FISH as described before [46]. Briefly, the plates were removed from -20 , the fixative solution removed, and the plates were dried on a hot plate at $37^{\circ} \mathrm{C}$ overnight, followed by rehydration with $200 \mu \mathrm{L}$ of PBS. Cells were fixed with $200 \mu \mathrm{L}$ of $4 \%$ formaldehyde in PBS for $2 \mathrm{~min}$ at room temperature (RT) and washed 3 times for $5 \mathrm{~min}$ with PBS. Prewarmed pepsin solution $\left(100 \mathrm{~mL}\right.$ of $\mathrm{H}_{2} \mathrm{O}, 100 \mu \mathrm{L}$ of $37 \% \mathrm{HCl}$ [10.1 M HCl], and $100 \mathrm{mg}$ of pepsin [SigmaAldrich; catalog no. P7000-25G]) was used to degrade cell walls for $15 \mathrm{~min}$ at $37^{\circ} \mathrm{C}$ followed by 2 washing steps of 5 min with $200 \mu \mathrm{L}$ of PBS. The cells were then dehydrated with sequential 5-min 70\%, 90\%, and 100\% ethanol steps. The plates were dried $1 \mathrm{~h}$ at $37^{\circ} \mathrm{C}$. Next, $50 \mu \mathrm{L}$ of the hybridization solution containing the TelCy3 PNA probe was added to the plates $(95 \mu \mathrm{L}$ of $1 \mathrm{M}$ Tris, $\mathrm{pH} 7.0,812 \mu \mathrm{L}$ of $\mathrm{MgCl}_{2}$ solution [ $25 \mathrm{mM} \mathrm{MgCl}_{2}$, $9 \mathrm{mM}$ citric acid, $\left.82 \mathrm{mM} \mathrm{Na} 2 \mathrm{HPO}_{4}\right], 6.65 \mathrm{~mL}$ of deionized formamide, $475 \mu \mathrm{L}$ of blocking reagent $[10 \mathrm{~g}$ of blocking reagent (Boehringer; catalog no. 1093 657) dissolved with heat in $100 \mathrm{~mL}$ of maleic acid buffer, $\mathrm{pH}$ $7.5(100 \mathrm{mM}$ maleic acid, $150 \mathrm{mM} \mathrm{NaCl})], 1.28 \mathrm{~mL}$ of $\mathrm{H}_{2} \mathrm{O}$, and $190 \mu \mathrm{L}$ of Tel-Cy3 PNA probe [5 $\mu \mathrm{g}$ lyophilized $\mathrm{Cy} 3-(\mathrm{C} 3 \mathrm{TA} 2) 3$ PNA probe (Panagene) diluted in $200 \mu \mathrm{L}$ of $\left.\mathrm{H}_{2} \mathrm{O}\right]$ ). Plates were then sealed with aluminum foil lids. The DNA was denatured by heating the plate on a hot plate at $85^{\circ} \mathrm{C}$ for $5 \mathrm{~min}$ and left to incubate for $2 \mathrm{~h}$ at RT in the dark. The plates were rinsed and washed in plate shaker with wash solution 1 (10 mM Tris- $\mathrm{HCl} \mathrm{pH} \mathrm{7,} \mathrm{70 \%} \mathrm{Formamide,} 0.10 \%$ BSA in $\mathrm{H}_{2} \mathrm{O}$ ) for $30 \mathrm{~min}$, followed by 3 washes of 5 min each with wash solution 2 (TBS [Tris-buffered saline, $\mathrm{pH}$ 7.0] with $0.08 \%$ Tween 20). Nuclei staining was performed incubating for 10 min with TBST containing $1 \mu \mathrm{g} / \mathrm{mL}$ DAPI (4',6-diamidino-2-phenylindole, dihydrochloride; Life Technologies; catalog no. D1306). Then the plates were washed $1 \times 5$ min with PBS and stored at $4^{\circ} \mathrm{C}$ in the dark. Images from the plate were then acquired by HT microscopy within $48 \mathrm{~h}$.

\section{High-throughput microscopy}

Quantitative image acquisition was performed on an Opera High Content Screening System (PerkinElmer) $40 \times / 0.9$ N.A. water-immersion objective. UV and 561 $\mathrm{nm}$ excitation wavelengths were used to detect DAPI and $\mathrm{Cy} 3$ telomeric signals, respectively and 60 
independent images were captured at different positions of each well. Images were analyzed with Acapella Image analysis software (PerkinElmer). Data were analyzed with SPSS (IBM) and Excel (Microsoft). Telomere fluorescence values were converted into kilobases by external calibration with the CCRF-CEM (7.5 kb), L5178Y-S (10.2 kb), L5178Y-R (79.7 kb) and Jurkat $(11.5 \mathrm{~kb})$ cell lines.

\section{Criteria for the diagnosis of COVID-19}

Depending on the clinical features of COVID-19, patients are generally divided as mild, moderate, severe and acute.

1. Mild COVID-19: low-grade fever, cough, malaise, rhinorrhea, sore throat with or without hemoptysis, nausea, vomiting, diarrhea, but without any radiological features of pneumonia and absence of mental changes.

2. Moderate COVID-19: fever, respiratory symptoms including dry cough and shortness of breath that may emerge along with the radiological features.

3. Severe COVID-19: dyspnea, respiratory frequency $\geq 30 /$ minute, blood oxygen saturation $\leq 93 \%$, $\mathrm{PaO} 2 / \mathrm{FiO} 2$ ratio $<300$, and/or lung infiltrates $>50 \%$ of the lung field within $24-48 \mathrm{~h}$.

4. Acute COVID-19: usually develops after 7 days in patients with mild/moderate/severe COVID-19 with features of Acute respiratory distress syndrome (ARDS) requiring mechanical ventilation along with presence of multiorgan dysfunction failure, metabolic acidosis and coagulation dysfunction.

\section{Data availability statement}

The data that support the findings of this study are available from the corresponding author upon reasonable request.

\section{AUTHOR CONTRIBUTIONS}

MAB had the original idea and secured funding. MAB and PM supervised research and wrote the paper. RSV, AGC and PM analyzed the data and performed experiments. AZG provided blood samples and clinical information.

\section{CONFLICTS OF INTEREST}

MAB is founder and holds shares of Life Length SL, a Biotech company that measures telomere length for biomedical uses.

\section{FUNDING}

We thank D. Megias and G. Mata for their help in confocal microscopy. Research in the Blasco lab is funded by the Spanish Ministry of Science and Innovation Projects (SAF2017-82623-R and SAF201572455-EXP), the Comunidad de Madrid Project (B2017/BMD-3770), the World Cancer Research (WCR) Project (16-1177) and the Fundación Botín (Spain). R.S-V is a recipient of a doctoral scholarship from CONACYT-México.

\section{REFERENCES}

1. Han C, Duan C, Zhang S, Spiegel B, Shi H, Wang W, Zhang L, Lin R, Liu J, Ding Z, Hou X. Digestive symptoms in COVID-19 patients with mild disease severity: clinical presentation, stool viral RNA testing, and outcomes. Am J Gastroenterol. 2020; 115:916-23. https://doi.org/10.14309/ajg.0000000000000664 PMID:32301761

2. Li YC, Bai WZ, Hashikawa T. The neuroinvasive potential of SARS-CoV2 may play a role in the respiratory failure of COVID-19 patients. J Med Virol. 2020; 92:552-55.

https://doi.org/10.1002/jmv.25728

PMID: $\underline{32104915}$

3. Tam CF, Cheung KS, Lam S, Wong A, Yung A, Sze M, Lam YM, Chan C, Tsang TC, Tsui M, Tse HF, Siu CW. Impact of Coronavirus Disease 2019 (COVID-19) Outbreak on ST-Segment-Elevation Myocardial Infarction Care in Hong Kong, China. Circ Cardiovasc Qual Outcomes. 2020.

https://doi.org/10.1161/CIRCOUTCOMES.120.006631 PMID:32182131

4. Hoffmann $\mathrm{M}$, Kleine-Weber $\mathrm{H}$, Schroeder $\mathrm{S}$, Krüger $\mathrm{N}$, Herrler T, Erichsen S, Schiergens TS, Herrler G, Wu NH, Nitsche A, Müller MA, Drosten C, Pöhlmann S. SARSCoV-2 cell entry depends on ACE2 and TMPRSS2 and is blocked by a clinically proven protease inhibitor. Cell. 2020; 181:271-80.e8.

https://doi.org/10.1016/j.cell.2020.02.052 PMID:32142651

5. Walls AC, Park YJ, Tortorici MA, Wall A, McGuire AT, Veesler D. Structure, Function, and Antigenicity of the SARS-CoV-2 Spike Glycoprotein. Cell. 2020; 181:28192.e6.

https://doi.org/10.1016/j.cell.2020.02.058 PMID:32155444

6. Wan Y, Shang J, Graham R, Baric RS, Li F. Receptor recognition by the novel coronavirus from Wuhan: an analysis based on decade-long structural studies of SARS coronavirus. J Virol. 2020; 94:e00127-20. 
https://doi.org/10.1128/JVI.00127-20

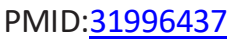

7. Wrapp D, Wang N, Corbett KS, Goldsmith JA, Hsieh CL, Abiona O, Graham BS, McLellan JS. Cryo-EM structure of the 2019-nCoV spike in the prefusion conformation. Science. 2020; 367:1260-63.

https://doi.org/10.1126/science.abb2507 PMID:32075877

8. Zhao Y, Zhao Z, Wang Y, Zhou Y, Ma Y, Zuo W. Singlecell RNA expression profiling of ACE2, the putative receptor of Wuhan 2019-nCov. bioRxiv, 2020.

9. Crackower MA, Sarao R, Oudit GY, Yagil C, Kozieradzki I, Scanga SE, Oliveira-dos-Santos AJ, da Costa J, Zhang L, Pei Y, Scholey J, Ferrario CM, Manoukian AS, et al. Angiotensin-converting enzyme 2 is an essential regulator of heart function. Nature. 2002; 417:822-28. https://doi.org/10.1038/nature00786 PMID:12075344

10. Danilczyk U, Penninger JM. Angiotensin-converting enzyme II in the heart and the kidney. Circ Res. 2006; 98:463-71.

https://doi.org/10.1161/01.RES.0000205761.22353.5f PMID:16514079

11. Ding $Y$, He L, Zhang $Q$, Huang $Z$, Che $X$, Hou J, Wang $H$, Shen H, Qiu L, Li Z, Geng J, Cai J, Han H, et al. Organ distribution of severe acute respiratory syndrome (SARS) associated coronavirus (SARS-CoV) in SARS patients: implications for pathogenesis and virus transmission pathways. J Pathol. 2004; 203:622-30. https://doi.org/10.1002/path.1560 PMID:15141376

12. Gu J, Gong E, Zhang B, Zheng J, Gao Z, Zhong Y, Zou W, Zhan J, Wang S, Xie Z, Zhuang H, Wu B, Zhong H, et al. Multiple organ infection and the pathogenesis of SARS. J Exp Med. 2005; 202:415-24. https://doi.org/10.1084/jem.20050828 PMID:16043521

13. Hamming I, Timens W, Bulthuis ML, Lely AT, Navis G, van Goor $\mathrm{H}$. Tissue distribution of ACE2 protein, the functional receptor for SARS coronavirus. A first step in understanding SARS pathogenesis. J Pathol. 2004; 203:631-37.

https://doi.org/10.1002/path.1570 PMID:15141377

14. Zhang $\mathrm{H}$, Penninger JM, Li Y, Zhong N, Slutsky AS. Angiotensin-converting enzyme 2 (ACE2) as a SARSCoV-2 receptor: molecular mechanisms and potential therapeutic target. Intensive Care Med. 2020; 46:586-90.

https://doi.org/10.1007/s00134-020-05985-9 PMID: $\underline{32125455}$

15. Ling $Y, X u S B$, Lin $Y X$, Tian D, Zhu ZQ, Dai FH, Wu F, Song ZG, Huang W, Chen J, Hu BJ, Wang S, Mao EQ, et al. Persistence and clearance of viral RNA in 2019 novel coronavirus disease rehabilitation patients. Chin Med J (Engl). 2020; 133:1039-43. https://doi.org/10.1097/CM9.0000000000000774 PMID: $\underline{32118639}$

16. Young BE, Ong SW, Kalimuddin S, Low JG, Tan SY, Loh J, Ng OT, Marimuthu K, Ang LW, Mak TM, Lau SK, Anderson DE, Chan KS, et al, and Singapore 2019 Novel Coronavirus Outbreak Research Team. Epidemiologic features and clinical course of patients infected with SARS-CoV-2 in Singapore. JAMA. 2020; 323:1488-94. https://doi.org/10.1001/jama.2020.3204 PMID:32125362

17. Wang $D, H u B, H u ~ C$, Zhu F, Liu $X$, Zhang J, Wang B, Xiang $\mathrm{H}$, Cheng $Z$, Xiong $\mathrm{Y}$, Zhao $\mathrm{Y}$, Li $\mathrm{Y}$, Wang $\mathrm{X}$, Peng $\mathrm{Z}$. Clinical characteristics of 138 hospitalized patients with 2019 novel coronavirus-infected pneumonia in Wuhan, China. JAMA. 2020; 323:1061-69. https://doi.org/10.1001/jama.2020.1585 PMID: 32031570

18. Tian S, Hu W, Niu L, Liu H, Xu H, Xiao SY. Pulmonary pathology of early-phase 2019 novel coronavirus (COVID-19) pneumonia in two patients with lung cancer. J Thorac Oncol. 2020; 15:700-04.

https://doi.org/10.1016/i.jtho.2020.02.010

PMID:32114094

19. Ruf BR, Knuf M. The burden of seasonal and pandemic influenza in infants and children. Eur J Pediatr. 2014; 173:265-76. https://doi.org/10.1007/s00431-013-2023-6 PMID:23661234

20. Bhat N, Wright JG, Broder KR, Murray EL, Greenberg ME, Glover MJ, Likos AM, Posey DL, Klimov A, Lindstrom SE, Balish A, Medina MJ, Wallis TR, et al, and Influenza Special Investigations Team. Influenzaassociated deaths among children in the United States, 2003-2004. N Engl J Med. 2005; 353:2559-67. https://doi.org/10.1056/NEJMoa051721 PMID:16354892

21. Finelli $L$, Fiore $A$, Dhara $R$, Brammer $L$, Shay $D K$, Kamimoto L, Fry A, Hageman J, Gorwitz R, Bresee J, Uyeki T. Influenza-associated pediatric mortality in the United States: increase of Staphylococcus aureus coinfection. Pediatrics. 2008; 122:805-11.

https://doi.org/10.1542/peds.2008-1336

PMID:18829805

22. Fleming DM, Pannell RS, Cross KW. Mortality in children from influenza and respiratory syncytial virus. J Epidemiol Community Health. 2005; 59:586-90. https://doi.org/10.1136/jech.2004.026450 PMID:15965143

23. Nair $H$, Brooks WA, Katz M, Roca A, Berkley JA, Madhi SA, Simmerman JM, Gordon A, Sato M, Howie S, 
Krishnan A, Ope M, Lindblade KA, et al. Global burden of respiratory infections due to seasonal influenza in young children: a systematic review and meta-analysis. Lancet. 2011; 378:1917-30.

https://doi.org/10.1016/S0140-6736(11)61051-9 PMID:22078723

24. Sachedina N, Donaldson LJ. Paediatric mortality related to pandemic influenza a H1N1 infection in England: an observational population-based study. Lancet. 2010; 376:1846-52.

https://doi.org/10.1016/S0140-6736(10)61195-6 PMID:21030071

25. Bellon $M$, Nicot C. Telomere dynamics in immune senescence and exhaustion triggered by chronic viral infection. Viruses. 2017; 9:289. https://doi.org/10.3390/v9100289 PMID:28981470

26. Blasco MA. Telomeres and human disease: ageing, cancer and beyond. Nat Rev Genet. 2005; 6:611-22. https://doi.org/10.1038/nrg1656 PMID:16136653

27. López-Otín C, Blasco MA, Partridge L, Serrano M, Kroemer G. The hallmarks of aging. Cell. 2013; 153:1194-217.

https://doi.org/10.1016/j.cell.2013.05.039

PMID:23746838

28. Blackburn EH. Structure and function of telomeres. Nature. 1991; 350:569-73. https://doi.org/10.1038/350569a0 PMID:1708110

29. de Lange T. Shelterin: the protein complex that shapes and safeguards human telomeres. Genes Dev. 2005; 19:2100-10.

https://doi.org/10.1101/gad.1346005 PMID:16166375

30. Martínez P, Blasco MA. Telomeric and extra-telomeric roles for telomerase and the telomere-binding proteins. Nat Rev Cancer. 2011; 11:161-76. https://doi.org/10.1038/nrc3025 PMID:21346783

31. Olovnikov AM. A theory of marginotomy. The incomplete copying of template margin in enzymic synthesis of polynucleotides and biological significance of the phenomenon. J Theor Biol. 1973; 41:181-90.

https://doi.org/10.1016/0022-5193(73)90198-7 PMID: $\underline{4754905}$

32. Watson JD. Origin of concatemeric T7 DNA. Nat New Biol. 1972; 239:197-201.

https://doi.org/10.1038/newbio239197a0 PMID: 4507727

33. Harley CB, Futcher AB, Greider CW. Telomeres shorten during ageing of human fibroblasts. Nature. 1990; 345:458-60.

https://doi.org/10.1038/345458a0 PMID:2342578

34. Vera E, Bernardes de Jesus B, Foronda M, Flores JM, Blasco MA. The rate of increase of short telomeres predicts longevity in mammals. Cell Rep. 2012; 2:732-7.

https://doi.org/10.1016/j.celrep.2012.08.023

PMID:23022483

35. Whittemore K, Vera E, Martínez-Nevado E, Sanpera C, Blasco MA. Telomere shortening rate predicts species life span. Proc Natl Acad Sci USA. 2019; 116:15122-27. https://doi.org/10.1073/pnas.1902452116 PMID:31285335

36. d'Adda di Fagagna F, Reaper PM, Clay-Farrace L, Fiegler H, Carr P, Von Zglinicki T, Saretzki G, Carter NP, Jackson SP. A DNA damage checkpoint response in telomereinitiated senescence. Nature. 2003; 426:194-98. https://doi.org/10.1038/nature02118 PMID:14608368

37. Greider CW, Blackburn EH. Identification of a specific telomere terminal transferase activity in tetrahymena extracts. Cell. 1985; 43:405-13.

https://doi.org/10.1016/0092-8674(85)90170-9 PMID: $\underline{3907856}$

38. Blasco MA, Lee HW, Hande MP, Samper E, Lansdorp PM, DePinho RA, Greider CW. Telomere shortening and tumor formation by mouse cells lacking telomerase RNA. Cell. 1997; 91:25-34. https://doi.org/10.1016/s0092-8674(01)80006-4 PMID: 9335332

39. Flores I, Cayuela ML, Blasco MA. Effects of telomerase and telomere length on epidermal stem cell behavior. Science. 2005; 309:1253-56.

https://doi.org/10.1126/science.1115025

PMID: 16037417

40. Herrera E, Samper E, Martín-Caballero J, Flores JM, Lee HW, Blasco MA. Disease states associated with telomerase deficiency appear earlier in mice with short telomeres. EMBO J. 1999; 18:2950-60.

https://doi.org/10.1093/emboj/18.11.2950 PMID:10357808

41. Lee HW, Blasco MA, Gottlieb GJ, Horner JW 2nd, Greider CW, DePinho RA. Essential role of mouse telomerase in highly proliferative organs. Nature. 1998; 392:569-74. https://doi.org/10.1038/33345 PMID: $\underline{9560153}$

42. Armanios $\mathrm{M}, \mathrm{Blackburn} \mathrm{EH}$. The telomere syndromes. Nat Rev Genet. 2012; 13:693-704. https://doi.org/10.1038/nrg3246 PMID:22965356

43. Povedano JM, Martinez P, Flores JM, Mulero F, Blasco MA. Mice with pulmonary fibrosis driven by telomere dysfunction. Cell Rep. 2015; 12:286-99. https://doi.org/10.1016/i.celrep.2015.06.028 PMID:26146081

44. Povedano JM, Martinez P, Serrano R, Tejera Á, GómezLópez G, Bobadilla M, Flores JM, Bosch F, Blasco MA. 
Therapeutic effects of telomerase in mice with pulmonary fibrosis induced by damage to the lungs and short telomeres. Elife. 2018; 7:e31299. https://doi.org/10.7554/eLife.31299 PMID:29378675

45. Cawthon RM. Telomere length measurement by a novel monochrome multiplex quantitative PCR method. Nucleic Acids Res. 2009; 37:e21.

https://doi.org/10.1093/nar/gkn1027 PMID:19129229

46. Canela A, Vera E, Klatt P, Blasco MA. High-throughput telomere length quantification by FISH and its application to human population studies. Proc Natl Acad Sci USA. 2007; 104:5300-05. https://doi.org/10.1073/pnas.0609367104 PMID:17369361

47. Epel ES, Blackburn EH, Lin J, Dhabhar FS, Adler NE, Morrow JD, Cawthon RM. Accelerated telomere shortening in response to life stress. Proc Natl Acad Sci USA. 2004; 101:17312-15. https://doi.org/10.1073/pnas.0407162101 PMID:15574496

48. Valdes AM, Andrew T, Gardner JP, Kimura M, Oelsner E, Cherkas LF, Aviv A, Spector TD. Obesity, cigarette smoking, and telomere length in women. Lancet. 2005; 366:662-64.

https://doi.org/10.1016/S0140-6736(05)66630-5

PMID:16112303

49. Zhang YZ, Holmes EC. A Genomic Perspective on the Origin and Emergence of SARS-CoV-2. Cell. 2020; 181:223-27. https://doi.org/10.1016/j.cell.2020.03.035 PMID:32220310

50. Bernardes de Jesus B, Vera E, Schneeberger K, Tejera AM, Ayuso E, Bosch F, Blasco MA. Telomerase gene therapy in adult and old mice delays aging and increases longevity without increasing cancer. EMBO Mol Med. 2012; 4:691-704.

https://doi.org/10.1002/emmm.201200245

PMID:22585399

51. Martínez P, Blasco MA. Telomere-driven diseases and telomere-targeting therapies. J Cell Biol. 2017; 216:875-87. https://doi.org/10.1083/jcb.201610111 PMID:28254828 